\title{
Calendar of Events
}

November 30 - December 3, 1989. American Back Society Fall Symposium on Back Pain will be held in Las Vegas, U.S.A. Contact: American Back Society, 2647 East 14th Street, Suite 401, Oakland, CA USA 94601. Phone (415) 536-9929.

December 1-2, 1989. Genes, Brain and Behavior meeting will be held in New York City, USA. Contact: Ivan BodisWollner, M.D., Secretary-Treasurer, ARNMD, Box 1052, Mt. Sinai Hospital, 1 Gustave Levy Place, New York, NY USA 10029. Phone (212) 348-8133.

December 2-7, 1989. The American Epilepsy Society Annual Meeting will be held in Boston, Massachusetts. For information contact: the American Epilepsy Society, 179 Allyn Street, Suite 304, Hartford, Connecticut USA 06103 or phone (203) 246-6566.

December 4-6, 1989. Presynaptic Receptors - An Examination of Different Views meeting, sponsored by the New York Academy of Sciences will be held in Philadelphia USA. Dead'ine for abstracts is September 1, 1989. Contact: Conference Department, The New York Academy of Sciences, 2 East 63rd Street, New York, NY USA 10021. Phone (212) 838-0230.

January 14-19, 1990. XII International Congress of Electroencephalography and Clinical Neurophysiology will be held in Rio de Janeiro, Brazil. Contact: General Secretariat, Robert Low, SHIN, QL 2, conj. 11, casa 14, 71.500 Brasilia, DF, Brasil.

January 21-27, 1990. Advances in Neurology course will be held in Islamorado, Florida USA. Contact: Millie F. Walden, Executive Secretary, 3425 S.W. 2nd Avenue, \#153, Gainesville, Florida USA 32607. Phone (904) 374-6058 or 373-9765.

February 1-3, 1990. 13th Annual course: Neurology for Non-Neurologists will be held in San Diego USA. Contact: Edith S. Bookstein/NNN, P.O. Box 2586, La Jolla, CA USA
92038. Phone (619) 454-3212.

February 14-16, 1990. 23rd Annual Recent Advances in Neurology will be held in San Francisco USA. Contact: (415) 476-4251.

April 2-4, 1990. Central and Peripheral Significance of Neuropeptide $Y$ and its Related Peptides meeting will be held in Baltimore USA. Contact: Conference Department, The New York Academy of Sciences, 2 East 63rd Street, New York, NY USA 10021. Phone (212) 838-0230.

April 1.8, 1990. Pathophysiological and Compensatory Events during Cerebral Ischemia and Post-Ischemic Edema course will be held in Erice-Trapani-Italy. Contact: Prof. Carlo Alvisi, Cattedra di Neurochirurgia, Istituto di Neurologia, Via Foscolo 7, 40123, Bologna, Italy. Phone $0039 / 51 / 585158$.

June 26-30, 1990. The Canadian Congress of Neurological Sciences will hold its XXVth Annual Meeting in Banff, Alberta. For further information contact: The Canadian Congress of Neurological Sciences, Secretariat Office, P.O. Box 4220, Station C, Calgary, AB Canada T2T 5N1. Phone (403) 229-9544.

June 20-23, 1990. The Second International Cleveland Clinic Epilepsy Symposium entitled "Epilepsy Surgery" will be held in Cleveland, Ohio. For further information contact: The Cleveland Clinic Educational Foundation, 9500 Euclid Avenue, Room TT-31, Cleveland, OH USA 441955241. Phone (216) 444-5696 (local), (800) 762-8172 (Ohio), (800) $762-8173$ (other).

June 1-6, 1991. The Fifteenth International Symposium on Cerebral Blood Flow and Metabolism will be held in Miami, Florida. Deadline for abstracts is October 15, 1990. For further information contact: Ms. Jenny Bernal, Conference Coordinator, BRAIN-91, University of Miami Conference Center, 400 SE Second Avenue, Fourth Floor, Miami, Florida USA 33131. 